\title{
PICKERING EMULSION TECHNOLOGY IN FABRICATE CELLULOSE FOAM FROM OIL PALM EMPTY FRUIT BUNCH WASTE
}

\author{
P. Amanda ${ }^{1}$, S. Nabila ${ }^{2}$ Ismadi $^{1}$, D. Purnomo ${ }^{1}$ and N. Masruchin ${ }^{1}$ \\ ${ }^{1}$ Research Center for Biomaterial, Indonesian Institute of Sciences, \\ Jl Raya Jakarta Bogor Km 46, Cibinong 16911, Indonesia \\ ${ }^{2}$ Department of Agricultural Engineering, Faculty of Agricultural Technology, \\ Brawijaya University, Malang 65145, Indonesia \\ E-mail: putri.amanda@lipi.go.id
}

Received: 7 January 2021

Revised: 15 April 2021

Accepted: 22 April 2021

\begin{abstract}
PICKERING EMULSION TECHNOLOGY IN FABRICATE CELLULOSE FOAM FROM OIL PALM EMPTY FRUIT BUNCH WASTE. Cellulose from the oil palm empty fruit bunch (OPEFB) waste can make a porous material. This study aims to make cellulose foam with Pickering emulsion technology used cellulose nanofiber as a Pickering agent. The mechanism of Pickering emulsion is learned from foamability and stability of foam in the presence of various concentrations of surfactant. The result showed that using Pickering emulsion technology only needed surfactant with a small concentration to improve foamability and stability. The addition of CNF indeed improved the stability and foamability with the Pickering effect. The stability test shows that the foam stabilized with CNF appeared to be relatively stable. In contrast to the CNF free system, the foams were collapse in three days tested. Structures of foam was characterized using an optical microscope and showed that the foam was composed into two- or three-dimensional microstructures formed by gas bubble of wet foam in random orientations. This process generated the lightweight Cellulose foam from OPEFB waste, with a density of $0.07 \mathrm{~g} / \mathrm{cm}^{3}$. Using Pickering emulsion technology to make cellulose foam can be one way to overcome OPEFB waste and this foam is potential for various applications.
\end{abstract}

Keywords: Cellulose Foam, Pickering Emulsion, Oil Palm Empty Fruit Bunch, Foamability

\begin{abstract}
ABSTRAK
TEKNOLOGI EMULSI PICKERING DALAM PEMBUATAN BUSA SELULOSA DARI LIMBAH TANDAN KOSONG KEPALA SAWIT. Selulosa pada limbah tandan kosong kelapa sawit (TKKS) dapat digunakan untuk membuat bahan berpori. Tujuan penelitian ini untuk membuat busa selulosa dari TKKS dengan menggunakan teknologi emulsi pikering dengan menggunakan Selulosa nanofiber sebagai agen pikering. Mekanisme emulsi pickering pada pembuatan busa selulosa ini dipelajari dari kemampuan menghasilkan busa ( foamabilitas) dan stabilitas busa pada berbagai variasi konsentrasi surfaktan. Hasilnya menunjukkan bahwa dengan menggunakan teknologi pickering hanya dibutuhkan surfaktan dengan kosentrasi kecil untuk meningkatkan foamabilitas dan stabilitas busa. Uji stabilitas menunjukkan bahwa busa selulosa dengan CNF lebih stabil, berbeda dengan sistem tanpa CNF dimana busa hancur dalam tiga hari pengujian. Karakterisasi struktur dengan mikroskop digital menunjukkan bahwa mikrostruktur busa selulosa dalam bentuk dua atau tiga dimensi dalam orientasi acak sesuai arah gelembung pada saat busa basah. Busa selulosa yag dihasilkan sangat ringan dengan densitas $0,07 \mathrm{~g} / \mathrm{cm}^{3}$. Penggunaan teknologi emulsi pickering pada pembuatan busa selulosa dari limbah TKKS
\end{abstract}


dapat menjadi salah satu cara dalam mengatasi limbah TKKS dan material berpori berbahan dasar selulosa yang

dihasilkan sangat potensial untuk berbagai aplikasi.

Kata kunci: Busa Selulosa, Emulsi Pickering, Tandan Kosong Kelapa Sawit, Foamabilitas

\section{INTRODUCTION}

Palm Oil is one of the cultivation plants producing vegetable oil in the form of Crude Palm Oil (CPO), very much grown in plantations in Indonesia and It makes Indonesia became one of the topmost important oil palm producers in the world. [1]. The Directorate General of Estate Indonesia data projected oil palm land area in Indonesia in 2019 is about 14,677,560 ha, with development at $25.42 \%$ from 2016 to 2017 . For export requirements, the Indonesian Palm Oil Association (GAPKI) states that $70 \%$ of palm production is allocated in 2018. However, the advantage of oil palm in Indonesia also has a dark side, one of them is the oil palm plantations waste that can also pollute the environment. [2].

Oil palm empty fruit bunch (OPEFB) is one of the most significant agricultural wastes generating in the palm oil industry [3]. On average, one hectare (ha) of oil palm plantation can produce 4-5 tons of OPEFB. This biomass waste has a time of 6-12 month for decomposition and which can cause environmental contamination if it is not properly handled [2]. One of the most important ingredients of OPEFB that can be utilized in other high-value products is cellulose. Cellulose is a natural polymer that can be used as a raw material for making fabrics, bioethanol, and bioplastics. Cellulose in OPEFB is $38.76 \%$ or about $37.50 \%$, with fiber content reaching $72.67 \%$. Because of the high content of cellulose [4].

Cellulose can be transformed into a variety of shape and applications such as nanocellulose, cellulosebased material biocomposite, or three-dimensional (3D) cellulose-based material $[5,6]$. Three-dimensional (3D) materials such as porous and lightweight are promising and attractive because of their versatile porosity, low density, large surface area, and surface roughness. [7]. Cellulose based foam is a novel low density, eco-friendly and biodegradable porous material. Cellulose foam is designed for a wide variety of engineering applications, such as packaging materials [8], building insulation [9], electrical applications [10], oil-water separation [11] and filtration materials [12]. In the commercial field of foams, various forms of synthetic polymer foams dominate. Replacing petroleum-based polymers with polymers from renewable and biodegradable resources such as cellulose foam is of particular interest $[5,13]$.

Many different ways can be used to prepare the foam material from cellulose, but particle-stabilized foams are a relatively recent development, where tailored particles are used to create high-stability foams [14]. This technique is closely connected to the Pickering emulsion technology, where the different phases are stabilized using solid particles. In contrast to when single surfactant molecules are adsorbed at the interface, the advantage of using solid particles instead of surfactants is a considerable improvement in free energy when the particles are adsorbed at the different phases interface[7].

Many types of particles can be used in Pickering emulsions technology, inorganic and organic particles. However, environmentally friendly organic particles such as nanocellulose is ideal Pickering agent to reinforced Cellulose foam [15]. In this study, we used cellulose from OPEFB waste to make foam material using Cellulose Nanofibril (CNF) as a stabilizer or Pickering agent. There are two primary criteria must be fulfilled for an emulsion to be called a stable emulsion. 1) The emulsions are stable for a long time against any phenomenon of destabilization such as coagulation, coalescence or Ostwald ripening; and 2) the emulsification process is possible. Long-term stability depends primarily on the formulation, but the process also matters, and stabilizing agents contribute a great deal as well. [20] and the addition of CNF as pickering agent serves to improve the foamability and stability of foam produced.

The pickering emulsion mechanism foam formation stabilized by nanocellulose is learned from foamability and foam stability. Foamability is studied by varying concentrations of surfactant as foaming agent. In this research We used SDS as foaming agent. SDS widely used as foaming agent in various industrial application before and used in more recent work on foam forming. SDS is an anionic surfactant which is low cost and high availability. It has good foaming properties because of its ability to rapidly diffuse to the air-water interface. SDS is composed of hydrophobic tail and hydrophilic head. Due to air hydrophobicity, the tail of 
the SDS stretches out of the solution into the air, while the head stays in the solution. [18]. The simple mechanical method using disperser and stirrer are used to assist SDS created air-water bubbles and then stabilized with CNF particles via Pickering effect. Foam stability is enhanced using a flocculant and foam structure characterized through density and porosity measurement and morphology using a 3D digital microscope.

\section{EXPERIMENTAL METHOD}

\section{Materials and Instruments}

The OPEFB kraft pulp was supplied by research center for Biomaterial LIPI, Cellulose content was $65.92 \%$. OPEFB pulp was bleached three times using alkali hydrogen peroxide. Cellulose nanofibril (CNF) $1.5 \mathrm{wt} \%$ derived from OPEFB kraft pulp obtained by mechanical treatment with Masuko Sangyo Super Masscolloider grinder (MKCA6-3; Masuko Sangyo Co., Ltd.). Sodium dodecyl sulfate (SDS) Ph.Eur Merck, and Cationic polyacrylamide (CPAM) technical grade. All chemicals were used without purification and distilled water was used in all experiments was lab-made.

Fabrication foam used Waring blender, Ultraturax IKA T-18, IKA Overhead Stirrer and Memert universal oven drying UN 30.

\section{Method and Procedure}

\section{Cellulose Foam Preparation}

The methodology of fabricating The cellulose foam from OPEFB is similar to the method reported by Liu et al. 2017 with modification [15]. Schematic description for the preparation of cellulose foam stabilized by Nanocellulose was shown in Figure 1. We were starting with dispersing Cellulose from OPEFB in distillated water $(1.5 \mathrm{wt} \%$ (dry fiber weight) in a certain ratio at $\mathrm{pH}$ 7.0). After that, the amount of SDS/CNF mixture added to cellulose slurry, the concentration of SDS is $0.25 ; 0.5$; 1; 1.5 ; and $2 \mathrm{~g} / \mathrm{L}$. The resulting SDS/CNF/Cellulose mixture system was rapidly mixed with an overhead stirrer at $1000 \mathrm{rpm}$ for 15 minutes with the volume foam and liquid drainage was count every 60 seconds. CPAM was added to the cellulose slurry after the beating process; and the dosage is $0.5 \mathrm{wt} . \%$ (on oven-dried fiber or o.d. pulp).

\section{Foamability and Pickering Emulsion Mechanisme}

The Pickering emulsion mechanism of the cellulose foam stabilized by CNF was investigated from the foamability and stability of foam formation. The effect of different surfactant concentrations defined the foamability in foam formation by measuring the foam volumes after blending by reading the graduated cylinder mark. The foam stability was learned by incubation the foam at room temperature for three days.

\section{Structure Characterization}

The densities of the Cellulose foams were determined from the dimensions and weights of the samples, and by using equation 1 [16], the density of the

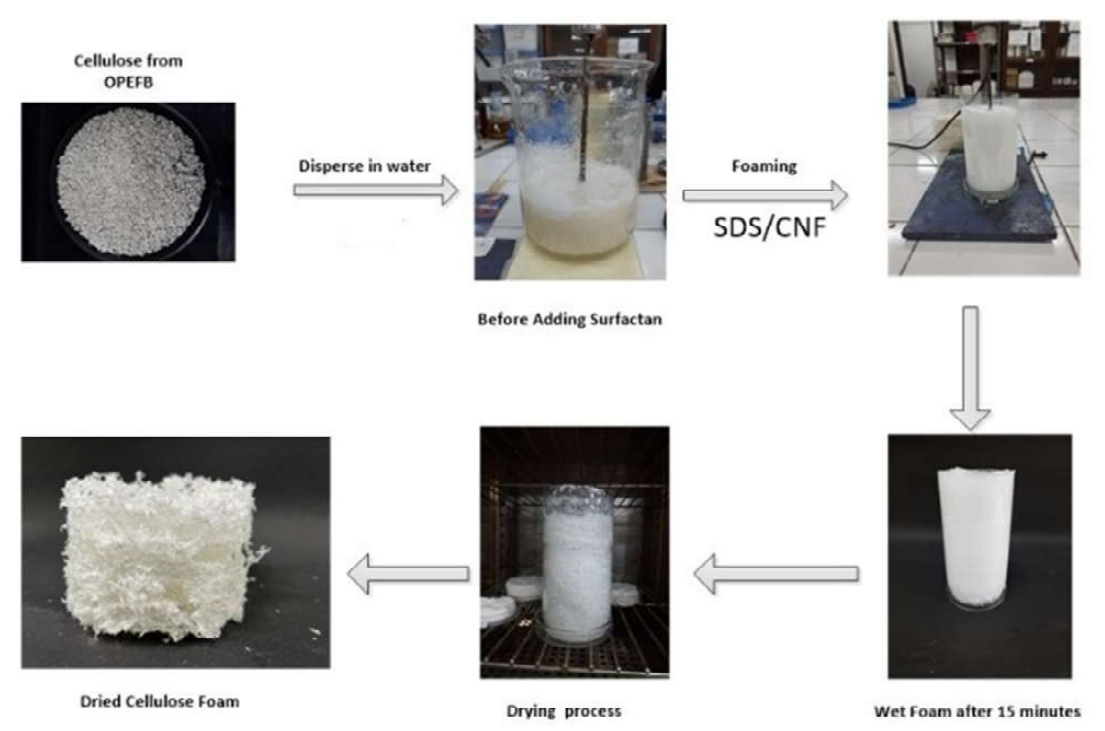

Figure 1. Schematic description one-step blending processes for the preparation of OPEFB Foam-stabilized by nanocellulose 
foams (da) and the density of the wood fibre $\left(\mathrm{dn} \approx 1.5 \mathrm{~g} / \mathrm{cm}^{3}\right)$ were used to calculate porosities.

Porosity $(\%)=\left(1-\frac{d_{a}}{d_{n}}\right) \times 100 \%$

The appearance of surface morfology and cross-section of cellulose foams were acquired using a 3D microscope Keyence VHX 6000.

\section{RESULT AND DISCUSSION}

\section{Effect of Surfactan Concentration in Foaming Properties of Cellulose Foam}

In this research, to obtain better insight into the critical chemical interactions between the surfactant and cellulose materials, the effect of surfactant concentration on a selected cellulose surfactant system was investigated and discussed.

The Pickering effect in the cellulose foam formation we learn by foamability properties. the foamability and foam stability were first studied by evaluation the volume foam at different concentrations of the surfactant sodium dodecyl sulphate (SDS).

Foam can be defined as dispersion of an air or gas in a water. The main phenomenon foaming properties of surfactant solution originates from adsorption of the surfactant at air/water interface which causes a decrease in interfacial tension between air/water. Foamability in the foaming process is related to the comparison of the amount of surfactant with other molecules, where the exact comparison of each other will produce foam in maximum volume. In foamability of surfactant, the Critical Micelle Concentration (CMC) value plays a role where maximum of foam volume will be formed when the concentration of surfactants is slightly above the CMC value [17].

Figure 2 (a) and (b) presented the data of foamability and liquid drainage for formulations cellulose foam in the presence of $0.25 ; 0.5 ; 1 ; 1.5$; and $2 \mathrm{~g} / \mathrm{L}$ of SDS. The data shown in Figure 2(a) shows that, with the various concentrations that we use in this research, a significant amount of foam is usually produced during the first minute $(60 \mathrm{~s})$ of stirring. After that, the foam volume increases gradually, the foam volume rate increases depending on the SDS concentration and the maximum foam volume attained after $15 \mathrm{~min}$ was varied. From the various SDS concentration, the most stable foam and remains virtually unchanged from the various SDS concentration further increases the stirring time was $0.25 \mathrm{~g} / \mathrm{L}$, the smallest concentration of SDS.

The CMC is the concentration at which the monomers begin to form micelles or a collection of surfactant molecular units. The critical micelle concentration (CMC) of Sodium Dodecyl Sulfate (SDS) in pure water was found to $2.4 \mathrm{~g} / \mathrm{L}$ at $25^{\circ} \mathrm{C}$ [18], however, in this study the foamability maximum obtained at the smallest concentration of SDS, not at the maximum concentration that is closer to the CMC value of SDS in water. This is influenced by the presence of CNF suspension as a pickering agent in the air/water emulsion system used. According to Nawal et.al, the addition of either cationic or anionic charged surfactants will decrease emulsion or suspension stability thereby lowering foamability, this is due to the formation of fibrils aggregate at air/water interface [19].

SDS is an anionic surfactant that plays a role in generating bubbles. The presence of CNF in emulsion systems as Pickering agent caused SDS react to surface of CNF. The higher the concentration of SDS, the greater (a)

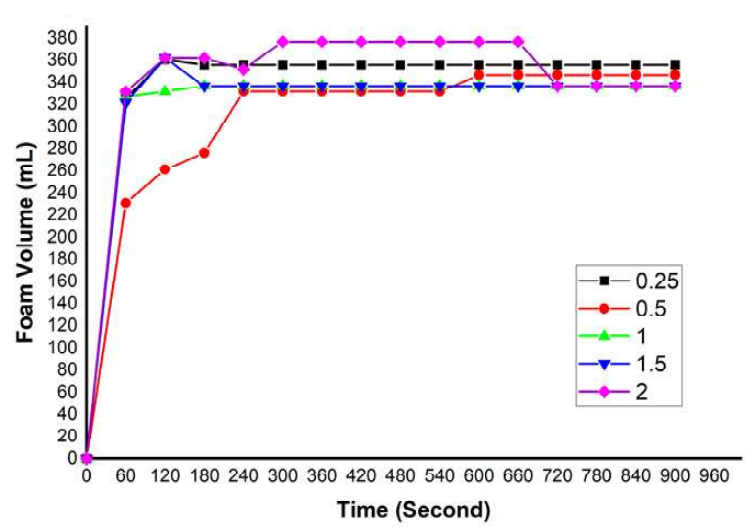

(b)

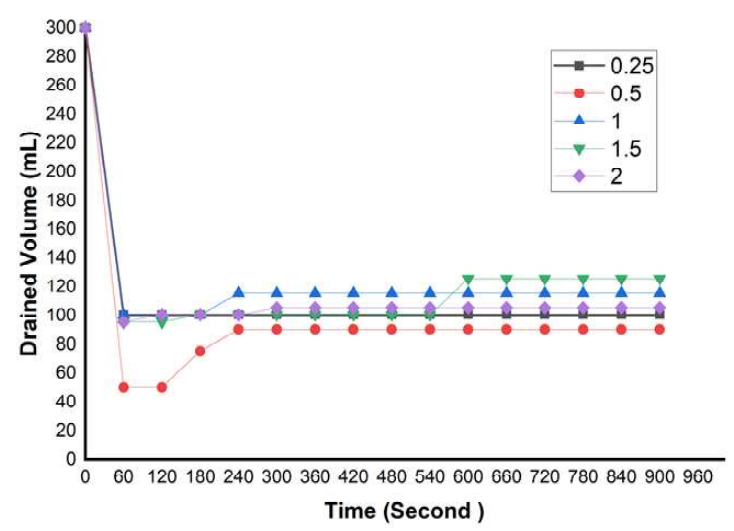

Figure 2. (a) Foamability of wet foam systems as function SDS concentration and (b) Drained Liquid Volume $($ vol system $=300 \mathrm{~mL})$ 
(a)

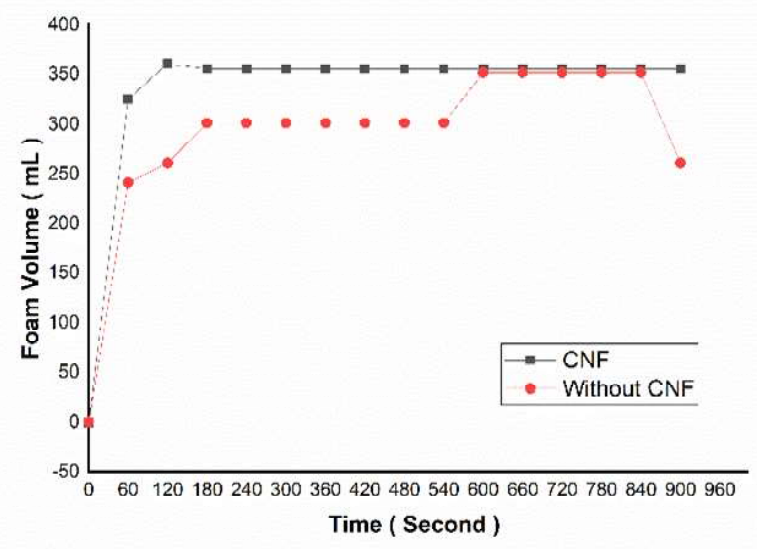

Figure 3. Pickering effect of CNF addition in (a) foaming properties and (b) foam stability (b)

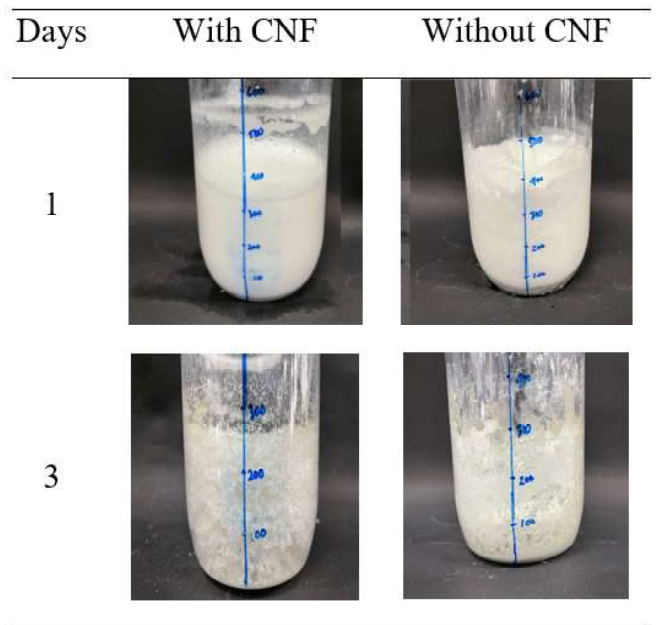

the interaction of SDS and CNF surface, so that not only a thin layer is formed on the interface bubbles (air)-water, but also forming fibrils aggregate which caused decrease the foamability and stability of foam. Mira et al. 2014 also conducted a study foaming behavior of the System with SDS as a surfactant. The results showed that the amount of fiber attached to SDS was influenced by the number of active substances in the fibers [17] .

\section{Pickering Effect of CNF to Cellulose Foam Stability}

Pickering effect of CNF can be seen in Figure 3. The foamability without CNF is lower than with CNF. As explained before, the $\mathrm{CMC}$ value of the SDS variation used is all below the CMC value of SDS in pure water. However, in Figure 3(a) with CNF the foamability and foam stability increased even at the smallest SDS concentration.
Furthermore, the foam stability can be seen in Figure 3(b). A crucial step when producing foam is to avoid Ostwald ripening and coalescence where air diffuser from smaller to larger bubble. The bubble coalescence depends on the competition between the rate of surfactant adsorption on the bubble surfaces and the drainage time of the foam films, formed between the air bubbles and the large air-water interface. If the adsorption rate is faster, the coalescence may be suppressed, due to the repulsion between the bubble and the large air-water interface which may arise only when the air-water intefaces are covered with a sufficient amount of adsorbed molecules. Figure 2(b) revealed that the foam stabilized with CNF appeared to be relative stable after three days. In contrast, in the foam without CNF, there is no films formed at air/water interface and rapidly thin to their critical thickness at which the attractive forces between the film surfaces dominate, the foam films break and the rate adsorption slower then

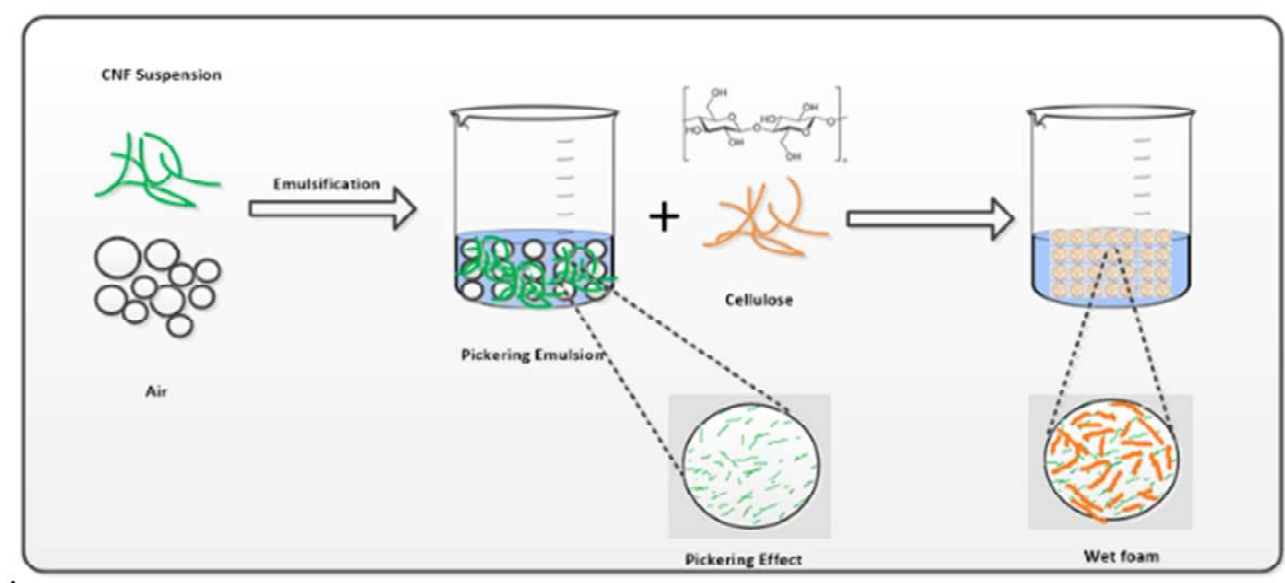

Figure 4. Pickering Emulsion mechanisme of CNF reiforced Cellulose foam Format 
the bubbles coalescence before the protective adsorption layer is formed.

\section{Pickering Emulsion Mechanisme in Cellulose Foam Formation}

The preparation process of making foam from the cellulose of OPEFB is illustrated in Figure 4, Starting dispersing $\mathrm{CNF}$ in water and mixed with SDS which created air/water bubbles and then stabilized with CNF particles via Pickering effect.

The basic idea in this investigation was to stabilize air bubbles with the CNF in aqueous suspension. Upon the adding of CNF, the particles adsorbs onto the air surface make rigid layer in liquid interfaces, forming the bubles stabilized air droplet. By reducing the surface energy of CNF and decreasing their inherent hydrophilic nature, it should be possible to stabilize the air bubbles.

\section{Structure of The Cellulose Foam Stabilized by CNF}

Through drying the wet foam stabilized by CNF, it was possible to obtain lightweight cellulose foam from OPEFB waste. The volumetric density and porosity of

Table 1. The desity and porosity of the Cellulose foam Stabilized by $\mathrm{CNF}$

\begin{tabular}{ccc}
\hline SDS $(\mathbf{g} / \mathbf{L})$ & $\begin{array}{c}\text { Density } \\
\left(\mathbf{g} / \mathbf{c m}^{3}\right)\end{array}$ & Porosity (\%) \\
\hline 0.25 & 0.07 & 95.34 \\
0.5 & 0.082 & 94.5 \\
1 & 0.074 & 95.04 \\
1.5 & 0.083 & 94.43 \\
2 & 0.094 & 93.75 \\
\hline
\end{tabular}

cellulose foam stabilized by CNF with various SDS concentrations are listed in Table 1.

Regardless of SDS concentration, cellulose foam was obtained, the density and porosity range was consistent with data from the literature for lightweight foam. Following the amount of foam volume produced, foam with SDS $0.25 \mathrm{~g} / \mathrm{L}$ has the lowest density value and the highest porosity, which is $0.07 \mathrm{~g} / \mathrm{cm}^{3}$ and $95.34 \%$ respectively. This density which are slightly lower than the densities of previously reported of CNF foam $\left(0.015 \mathrm{~g} / \mathrm{cm}^{3}\right)[9]$ and can comparable with kraft pulp and Thermomechanical pulp (TMP) foam by Lecourt et.al 2017 with density between $0.039-0.045 \mathrm{~g} / \mathrm{cm}^{3}$ [20]. The Porosity of Cellulose foam is $95.34 \%$ and its comparable with other porous materials. It is higher than nano paper (40-86\%) and equal to that of freeze dried aerogel $(93-99 \%)$ [21].

The best density value in SDS concentration of $0.25 \mathrm{~g} / \mathrm{L}$ is in accordance with the results of foamability test, whereby with the use of such concentrations produced the largest and stable foam volume.

Figure 5 shows the structure characteristic of cellulose foam revealed by $3 \mathrm{D}$ microscope. It is evident that this cellulose foam shows a structure with interconnected porous and open pores of different sizes. The microstructure can be characterized as a dense cellular structure with some randomly distributed pores whereas the upper part exhibits an oriented and highly porous structure, and the internal view of the foam walls shows a fibrillary-based structure. In particular, the cross section of the foam is shown in second raw of Figure 5.
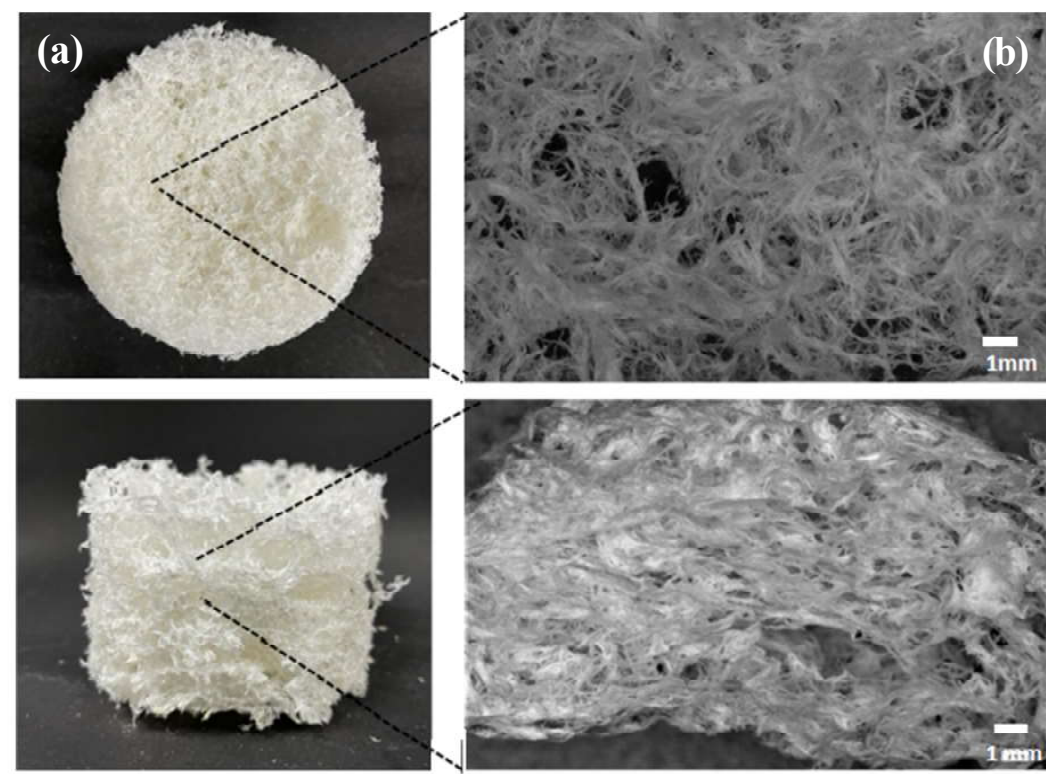

Figure 5. Microstructure of Cellulose foam from OPEFB, (a) surface and (b) cross-section (magnification 250x) 


\section{CONCLUSION}

In conclusion, our result illustrated a simple approach to produce cellulose foam from OPEFB waste with Pickering emulsion technology. The rate of foamability in the foams produced depends on the concentration of the surfactant. But the most stable wet foam and remains virtually unchanged by further increases the stirring time was the smallest concentration; $0.25 \mathrm{~g} / \mathrm{L}$. It is caused of the presence of CNF suspension as a Pickering agent. The stability test shows that the foam with Pickering agent relatively stable, In contrast to the CNF free system, the foams were collapse in three days tested. The structure investigation showed that cellulose foam with SDS/CNF system generated porous microstructure lightweight foam with a density of 0.07 $\mathrm{g} / \mathrm{cm}^{3}$. The cellulose foam from OPEFB has great potential for various application.

\section{ACKNOWLEDGEMENT}

This research was financially supported by Indonesia Oil Palm Estate Fund (Badan Pengelola Dana Perkebunan Kelapa Sawit [BPDPKS]), Ministry of finance, Republic of Indonesia, under contract no. PRJ01/DPKS/DIT.IV/2021. The authors acknowledge the facilities, and the scientific and technical assistance of the Integrated Laboratory of Bioproducts at the Indonesian Institute of Sciences.

\section{REFERENCES}

[1]. A.C. Sequiño and J. Avenido. "The World's Leader in the Palm Oil Industry/ : Indonesia." International Journal of Ecology and Conservation, vol. 13, pp.152-164, Jan. 2015.

[2]. M. Ikhsan and R. Ramli. "Measurements and analysis of crystal structures of activated carbon of empty fruit bunch from oil palm biomass waste," Journal of Physics: Conference Series, vol. 1528, no. 1,2020 .

[3]. H. Musa, P. C. Han, F. H. Kasim, S. C. B. Gopinath, and M. A. Ahmad. "Turning oil palm empty fruit bunch waste into substrate for optimal lipase secretion on solid state fermentation by Trichoderma strains." Process Biochemistry, vol. 63, pp.35-41, Dec. 2017.

[4]. D. P. Dewanti. "Potensi Selulosa dari Limbah Tandan Kosong Kelapa Sawit untuk Bahan Baku Bioplastik Ramah Lingkungan.” Jurnal Teknologi
Lingkungan, vol. 19, no. 1, pp.81, 2018.

[5]. A. Dufresne. "Nanocellulose: A new ageless bionanomaterial." Materials Today, vol. 16, no. 6, pp.220-227, Jun. 2013.

[6]. K. J. De France, T. Hoare, and E. D. Cranston. "Review of Hydrogels and Aerogels Containing Nanocellulose.” Chemistry of Materials, vol. 29, no. 11,pp.4609-4631, Apr. 2017.

[7]. N. T. Cervin, E. Johansson, P. A. Larsson, and L. Wågberg. "Strong, Water-Durable, and WetResilient Cellulose Nanofibril-Stabilized Foams from Oven Drying." ACS Applied Material Interfaces, vol. 8, no. 18, pp.11682-11689,Apr. 2016.

[8]. S. Ahmadzadeh, A. Nasirpour, J. Keramat, N. Hamdami, T. Behzad, and S. Desobry. "Nanoporous cellulose nanocomposite foams as high insulated food packaging materials." Colloids and Surfaces A: Physicochemical and Engineering Aspects, vol. 468, pp.201-210, Mar. 2015.

[9]. B. Wicklein et al. "Thermally insulating and fireretardant lightweight anisotropic foams based on nanocellulose and graphene oxide." Nature Nanotechnology, vol. 10, no. 3, pp.277-283, Nov. 2015.

[10]. J. Erlandsson, V. López Durán, H. Granberg, M. Sandberg, P. A. Larsson, and L. Wågberg. "Macroand mesoporous nanocellulose beads for use in energy storage devices." Applied Materials Today, vol. 5, pp.246-254, Dec. 2016.

[11]. H. Zhang et al.. "Super Light 3D Hierarchical Nanocellulose Aerogel Foam with Superior." Journal of Colloid and Interface Science, vol.536, pp.245-251, Feb. 2019.

[12]. S. Heydarifard, K. Taneja, G. Bhanjana, N. Dilbaghi, and M. M. Nazhad. "Modification of Cellulose Foam Paper for Use as a High-quality Biocide Disinfectant Filter for Drinking Water Modi fi cation of cellulose foam paper for use as a highquality biocide disinfectant fi lter for drinking water." Carbohydrate Polymer, vol. 181, no. June 2018, pp.1086-1092, Nov. 2017.

[13]. M. Rose and R. Palkovits. "Cellulose-based sustainable polymers: State of the art and future trends." Macromolecular Rapid Communications, vol. 32, no. 17, pp.1299-1311, Sep. 2011.

[14]. N. T. Cervin, E. Johansson, J. Benjamins Willem, and L. Wagberg. "On The Mechanisms Behind 
the Stabilizing Action of Cellulose Nanofibrils in Wet-Stable Cellulose Foams." Biomacromolecules, vol. 16, pp.822-831, Jan. 2015.

[15]. Y. Liu, S. Kong, H. Xiao, C. Y. Bai, P. Lu, and S. F. Wang. "Comparative study of ultra-lightweight pulp foams obtained from various fibers and reinforced by MFC." Carbohydrate Polymer, vol. 182, pp.92-97, Feb. 2018.

[16]. S. He et al.. "Bio-inspired lightweight pulp foams with improved mechanical property and flame retardancy via borate cross-linking." Chemical Engineering Journal, vol. 371, pp.34-42, Sep. 2019.

[17]. I. Mira et al.. "Foam forming revisited Part I. Foaming behaviour of fibre-surfactant systems." Nordic Pulp \& Paper Research Journal, vol. 29, no. 4, pp.679-688, Jul. 2014.

[18]. M. A. Motin, M. A. Hafiz Mia, and A. K. M. N. Islam. "Thermodynamic properties of Sodium Dodecyl Sulfate aqueous solutions with Methanol,
Ethanol, n-Propanol and iso-Propanol at different temperatures." Journal of Saudi Chemical Society, vol. 19, no. 2, pp.172-180, Mar. 2015.

[19]. N. Quennouz, S. M. Hashmi, H. S. Choi, J. W. Kim, and C. O. Osuji. "Rheology of cellulose nanofibrils in the presence of surfactants." Soft Matter, vol. 12, no. 1, pp.157-164, Oct. 2015.

[20]. M. Lecourt, T. Pöhler, J. Hornatowska, L. Salmén, and P. Jetsu. "Density profiles of novel kraft pulp and TMP based foam formed thermal insulation materials observed by X-ray tomography and densitometry." Holzforschung, vol. 72, no. 5, pp.397-403, Feb. 2018.

[21]. H. Sehaqui, Q. Zhou, and L. A. Berglund. "Highporosity aerogels of high specific surface area prepared from nanofibrillated cellulose (NFC)." Composites Science and Technology, vol. 71, no. 13,pp.1593-1599, Sep. 2011. 